\title{
Ethnic Pattern of Mushroom Consumption in Delta State Nigeria
}

\author{
IHAYERE, CA; *IGBEN, JL \\ Department of Environmental Management and Toxicology, Western Delta University, Oghara, Nigeria \\ *Corresponding Author Email: joma_igben@yahoo.com; Tel.08034037691
}

\begin{abstract}
This study examines the frequency of mushroom consumption among the various ethnic groups in Delta State, Nigeria. Primary data were obtained from a structured questionnaire administered on a sample of 240 respondents randomly selected from 6 settlements, one each from the six ethnic groups in the study area. The result reveals a variation in the proportion and frequency of mushroom consumption among the various ethnic groups. Urhobo with 12 consumers (30\%) (Very high 1, high 2, Low 3 and very low 6 frequency), Isoko with 14 consumers (35\%) (Very high 2, high 4, Low 3 and very low 5 frequency), Itsekiri with 18 consumers (45\%) (Very high 0 , high 2, Low 4 and very low 12 frequency), Ijaw with 18 consumers (45\%) (Very high 1, high 2, Low 4 and very low 10 frequency), Ukwuani with 36 consumers (90\%) (Very high 14, high 11, Low 6 and very low 5 frequency), Ibo with 38 consumers (95\%) (Very high 17, high 13, Low 6 and very low 2). Mushroom consumption was influenced by the availability of the fungi, which is dependent upon the ecology of the area. Consequently, the study recommends the cultivation of mushrooms to supplement the natural production of the fungi.
\end{abstract}

DOI: $\underline{\text { https://dx.doi.org/10.4314/jasem.v24i5.1 }}$

Copyright: Copyright $(\subset 2020$ Ihayere and Igben. This is an open access article distributed under the Creative Commons Attribution License (CCL), which permits unrestricted use, distribution, and reproduction in any medium, provided the original work is properly cited.

Dates: Received: 27 February 2020; Revised: 30 March 2020; Accepted: 17 April 2020

Keywords: Mushrooms, Mycophagy, Ecology, Delta State

Mushrooms are fleshy, sporous, umbrella shaped fruiting body of a fungus produced above the ground, mostly on dead decaying organic vegetative materials such as trees. They are typically of the Phyllum Basidiomycota class but some are also of other groups. However, in its broadest sense, mushrooms encompass toadstools, truffles, puffballs, stuckhorns, brackel, on wood and various other forms with distinctive fruiting body that is large enough to be picked by hand (Chang and Miles, 1992). There are four categories of mushrooms; namely, mycorrhizal, parasitic, saprotrophic, endophytic depending on their relationship with their host. Furthermore, mushrooms are either edible or poisonous. Edible mushrooms such as Amanita muscavia, Agaricus biosporus and Psilocybin are commonly classified as vegetables in the food world, but they are not technically plants. They belong to the fungi kingdom which contains an estimated 1.5 million species of non-photosynthetic organisms as distinct from the plant kingdom (Hall et al, 2003). They are harvested and consumed mostly in the rural areas for their nutritional value, an act known as Mycophagy, and occasionally for their perceived medicinal and economic values (Chang and Miles, 2004). The harvesting of mushrooms is an economic activity carried out by workers in the primary sector usually on part-time basis (Igben, 2014). Common mushrooms harvested in Nigeria include Termitomyces, Pleurotus, Lentinus, Trametes,
Ganoderma, Pycnoporus Cariolopsis etc. There is a plethora of studies and comments on the benefits and consumption of mushrooms, particularly in the rural areas. According to Jonathan (2002), mushrooms are luxury and important table delicacy especially among rural dwellers. Mushrooms such as T. robustus, $T$. globulus, V. esculenta, V. volvacea, $L$. subnudus and young sporophores of Tuber regium are usually served as alternative to meat. The protein level of mushrooms, as observed by Rambella and Nenini (1985) cited in Jonathan and Fasidi (2003), is twice that of potatoes and cabbage, and about four times that of tomatoes and carrot and six times that of oranges. Mushrooms are also known to be of high medicinal values that have not been adequately appreciated.

For instance, Oyetayo (2011) asserted that there is inadequate data on the identity and ethno-medicinal properties of wild mushrooms such as Pleurotus tuberregium used for headache, stomach pain, fever, cold and constipation; Lentinus squarrosulus for mumps, heart disease; Termitomyces microcarpus for gonorrhea; Calvatia cyathiformis for Leucorrhea, barrenness; Gornoderma lucidum for treating arthritics etc. They are also known to decrease risks of obesity and consequently overall mortality, diabetic and heart diseases. They are rich in antioxidants and promote healthy complexion and hair and increased energy. 
Similarly, a preliminary study of mushrooms injection on health conducted by the University of Buffalo (USA) nutrition scientists and physiologists in 2004 has found out that healthy male and female subjects who consume mushrooms with glucose had a significant lower glycemic response compare to those who consume glucose alone (Donovan, 2014). They are also known to contain selerium, which plays role in liver enzyme function and helps to detoxify cancercausing compounds. In addition, they act as biodegradable, thereby decreasing pollution and generating income in countries such as China, USA, Japan etc. (Yang et al, 2001; Hall et al, 2003). On the consumption of Mushrooms, Adedokun and Okomadu's (2017) study assesses the perception of consumers of wild and cultivated mushrooms in Port Harcourt (Urban area) and to validate the nutritional quality and value of mushrooms. The study revealed that $47.8 \%$ of the 90 respondents were introduced to mushroom consumption through family members, $53.3 \%$ were conversant with wide mushrooms, $27.8 \%$ were with cultivated mushrooms and $16.7 \%$ with both, A total of $71.1 \%$ were aware of mushroom poisoning. Kalu et al (2013) revealed that fungi misconception, unavailability and seasonal scarcity are some of the major problems militating against mushroom consumption in Nigeria. In the same vein, Okhuoya et al (2010) highlighted the trend of mushroom appreciation in Nigeria stressing the problems associated with exploration and exploitation of this valuable fungi. The authors further stated that mushrooms are exploited for food and medicine, particularly among the Yoruba speaking people; hence, the idea of ethnic mycophagy. However, there has not been any known study on the frequency of consumption of mushrooms based on ethnicity generally in the study area; hence, this study analyses the ethnic pattern of mushroom consumption. Specifically, its aim is to ascertain the frequency of mushroom consumption among the various ethnic groups in Delta State, Nigeria

\section{MATERIALS AND METHOD}

Study Area: Delta State lies roughly between Latitudes $5^{\circ} 00^{\prime}$ and $6^{0} 30^{\prime}$ north and Longitudes $5^{\circ} 00^{\prime}$ and $6^{0} 45^{\prime}$ east, over an area of 22,159 square kilometres, of which more than 60 per cent is land. The state is bordered in the north by Edo State, by Ondo State to the northwest, Anambra State to the east and Bayelsa State to the southeast. On its southern flank is the Bight of Benin, which covers approximately 160 kilometres of the state's coastline. The state is divided into twenty-five political divisions called Local Government Areas (LGAs).

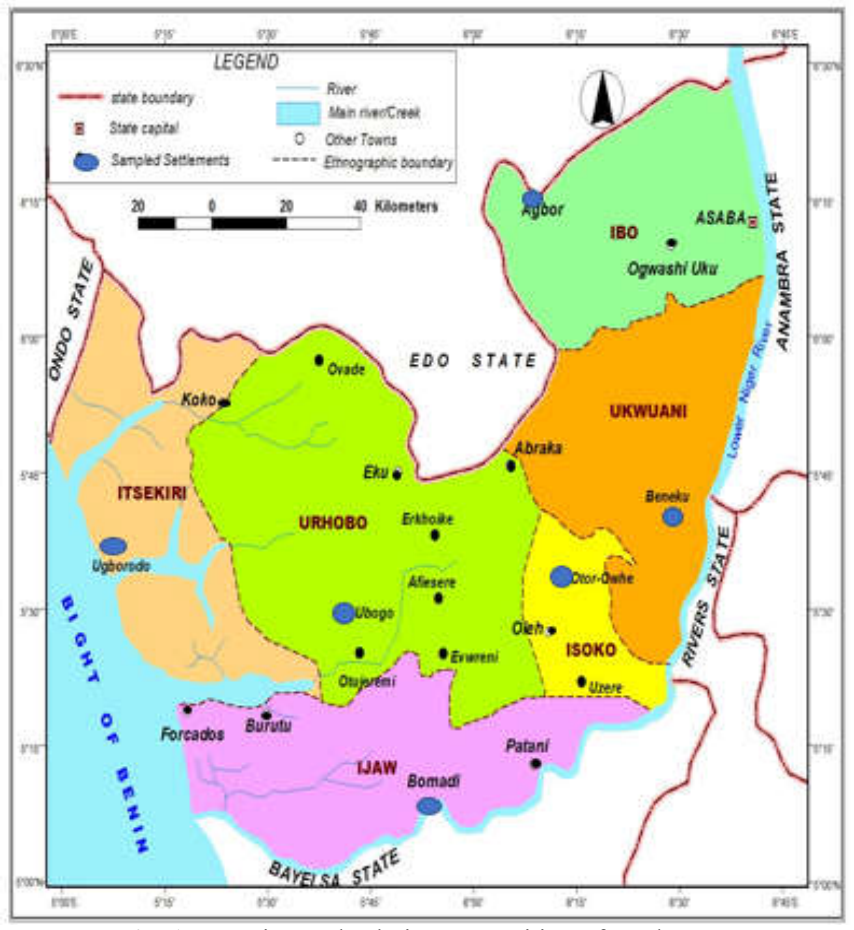

Fig. 1: Location and Ethnic Composition of Study Area

Furthermore, the state consists of four ecological zones of coastal barrier island or ridges, mangroves, freshwater swamp forest and lowland rainforest like other states in the Niger Delta region. These zones were classified by Ikporukpo (1996) into two, namely, the outer delta; which comprise muddy sheltered 
creeks, deltas, brackish and or strong tidal waters characterized by mangrove (Rhizophora race mosa) as the most common plant. Associated with the mangrove forest are Conocarpus erectus and other woody species that grow at the edge of the swamps, mainly near the sea. The south also has freshwater swamps, noted for floating grass, screw pine (Pandanas candelebrum) and raffia palm (Raphia hookeri) as the most common tree types. The inner delta, is made up predominantly of swamp rainforest which is not as wet. The zone comprises wet lowland evergreen rainforest in the north and mangrove forests in the south. The different ecological zones provide habitation for different species of plants, mushrooms, fishes, reptiles, mammals and minerals on which the population depends.

The 2006 provisional national population census put the population of Delta State at 4,098, 391 persons, made up of 2,074,306 males and 2,024,085 females (NPC, 2006). The state has an estimated population of over 5 million in 2017 using the annual growth rate of 2.5 percent. The population consists of many diverse, but related ethnic groups. Among the indigenous groups are the Urhobo, Ijaw, Isoko and Itsekiri in the southern part of the state and Ibo and Ukwuani in the north as shown in Figure 1. The people of Delta State engage in a wide range of economic activities mostly in the primary sector, including agriculture and allied activities, fishing, lumbering, hunting, and tapping of rubber trees and raffia palm, gathering of fuel wood, collection of non-timber forest products like bamboo, palm nuts, screw pines, thatches, mushrooms, snails, fruits and herbs for medicinal purposes. Other economic activities are trading, manufacturing etc.

Population and Sample: Primary data for this study were obtained from a structured questionnaire administered on a sample population. A total of 240 respondents were chosen from 6 settlements, one each from the six ethnic groups in the study area. The settlements were randomly selected, using the table of random numbers from a list of 10 settlements identified in each of the six ethnic groups. The settlements and the ethnic group are, Ubogo (Urhobo), Otor-Owhe (Isoko), Ugborodo (Itsekiri), Bomadi (Ijaw), Beneku (Ukwuani) and Agbor (Ibo).

In each of the selected settlements, 40 households were targeted and randomly selected. The questionnaire forms, which covered the demographic characteristics of respondents and frequency of mushroom consumption, were distributed to the heads of the sampled households or their representatives who were made to fill them and return immediately to field assistants. At the end of the data collection exercise, all questionnaire forms $(100 \%)$ were returned from the selected settlements.

Data Analysis: Data collected for the study were coded and compacted into manageable size. The frequencies of occurrence of events and percentages were worked out and presented in tables and graphs.

\section{RESULTS AND DISCUSSION}

Table 1 shows that 129 household heads, representing 63.3 per cent, were above the age of 46 years. Out of this percentage, 26 persons or 10.8 per cent of them were in the age cohort of 46-50 years and those between 51-55 years old (31 persons or 12.9\%) and those in the 56-60 years with 39 persons or 16.3 per cent. Those above 60 years were 33 persons or 13.8 per cent. Those whose ages were between $41-45$ years were 34 persons or $14.2 \%$, and 12.1 per cent and 10.8 per cent respectively for 36-40 years and $41-45$ years old. The percentages became lower with decreasing ages, as those between 31-35 years, 26-30 years, 2025 years and below 20 years formed $10.8 \%, 6.7 \%$, $2.0 \%$ and $0.4 \%$ respectively.

Table 1: Age and Sex Composition of Sampled Population

\begin{tabular}{|l|l|l|l|l|l|}
\hline & $\begin{array}{l}\text { Age } \\
\text { Group }\end{array}$ & Male & Female & Total & Percentage \\
\hline 1 & $<20$ years & 1 & 0 & 1 & 0.4 \\
2. & $21-25$ & 3 & 2 & 5 & 2.0 \\
3. & $26-30$ & 7 & 9 & 16 & 6.7 \\
4. & $31-35$ & 12 & 14 & 26 & 10.8 \\
5. & $36-40$ & 16 & 13 & 29 & 12.1 \\
6. & $41-45$ & 20 & 14 & 34 & 14.2 \\
7. & $46-50$ & 18 & 8 & 26 & 10.8 \\
8. & $51-55$ & 21 & 10 & 31 & 12.9 \\
9. & $56-60$ & 23 & 16 & 39 & 16.3 \\
10. & $>60$ years & 25 & 8 & 33 & 13.8 \\
\multicolumn{5}{|c|}{ Source: Field work, 2019} \\
\hline
\end{tabular}

In addition, a majority of 146 household heads representing $60.8 \%$ were males representing 52.0 per cent in contrast to 94 household heads or $39.2 \%$ were females. Furthermore, majority of 193 respondents, representing 80.4 per cent were married. While 21 respondents or 8.8 were singles, 11 respondents (4.6\%) are divorced. Widows accounted for 15 respondents representing 6.2 per cent as depicted in Figure 2.

Sampled Population and proportion of Mushroom Consumers: Figure 3 below indicates the proportion of mushroom consumers among the six ethnic groups in the study area. Out of the 40 respondents sampled in each of the ethnic group, a total of 136 respondents, representing 56.7 percent consume mushroom for various reasons. In this category, the Urhobo ethnic 
group had 12 mushroom consumers or 30 percent. While Isoko had 14 mushroom consumers or 35 per cent, the Itsekiri and Ijaw had 18 consumers or 45 per cent each. The Ibo ethnic group had the highest number of consumers of 38 respondents or 95 per cent, and closely followed by Ukwuani with 36 respondents representing 90 per cent.

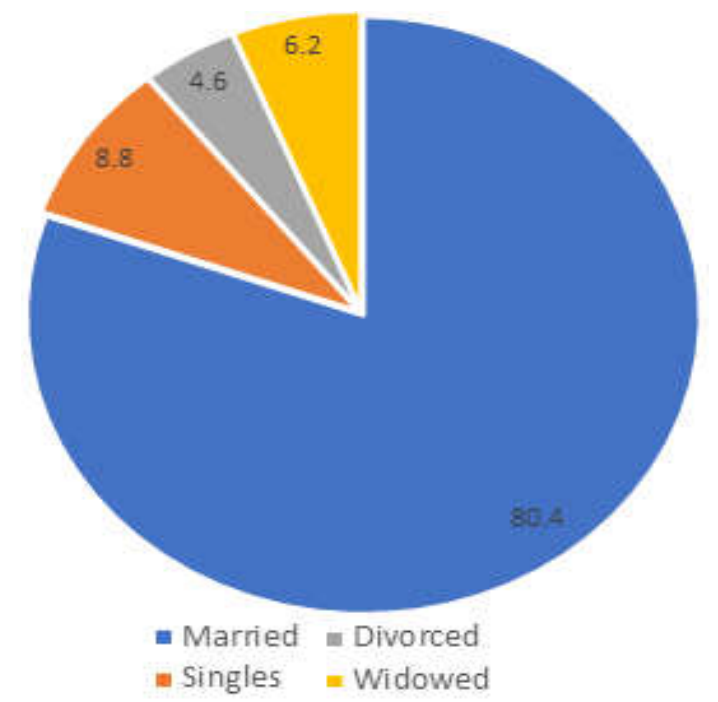

Fig 2: Marital Status of Respondents

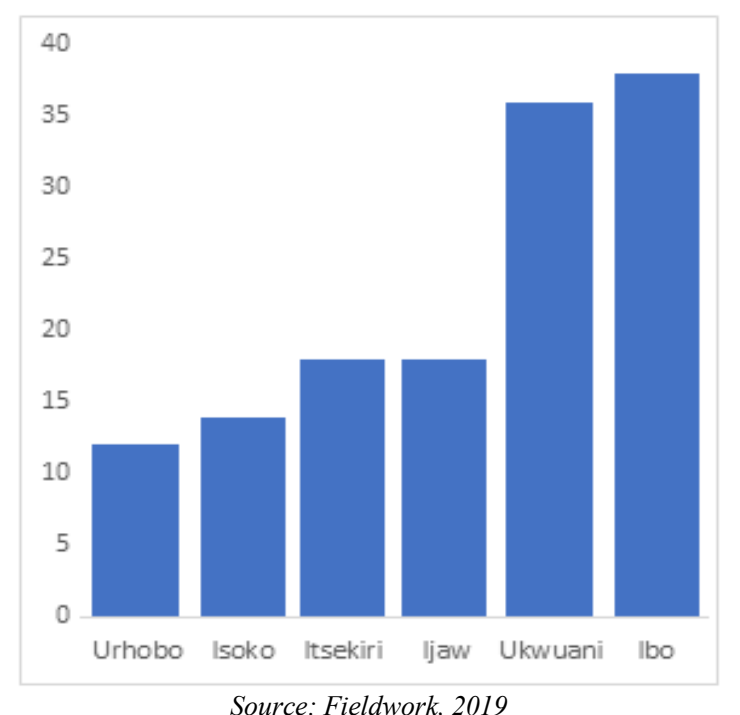

Fig 3: Proportion of Mushroom Consumers

Frequency of Mushroom Consumption: The table below shows the frequency of Mushroom consumption by the 136 respondents that consume the fungi. The table above shows that the frequency of mushroom consumption is rated very high, high. Low and very low. It further reveals that the Urhobo is the least consumers of mushroom. Of the 12 persons, representing $30 \%$ of the respondents that consume mushroom, the frequency of consumption is as follows; very high 1, high 2 . Low 3 and very low 6 respondents. This group is closely followed by Isoko with 14 respondents or 35 percent, in which 2, 4, 3, and 5 respondents with very high, high, low and very low frequency respectively. The Itsekiri and Ijaw groups had 18 respondents ( $45 \%$ of sample) each, with $0,2,4,12$ and 1, 2, 5, 10, in the high, high, low and very low frequency respectively. Ukwuani and Ibo groups had the highest number of mushroom consumers with 36 respondents or $90 \%$ and 38 respondents or $95 \%$ respectively. A breakdown of this statistics show that the Ukwuani had 14, 11, 6, and 5 respondents in very high, high, low and very low frequency category while the Ibo had 17, 13, 6, and 2 respondents in very high, high, low and very low frequency category respectively.

Table 2: Frequency of Mushroom Consumption

\begin{tabular}{|c|c|c|c|c|c|c|}
\hline $\mathrm{S} / \mathrm{N}$ & $\begin{array}{l}\text { Ethnic } \\
\text { Group }\end{array}$ & $\begin{array}{l}\text { Very } \\
\text { High }\end{array}$ & High & Low & $\begin{array}{l}\text { Very } \\
\text { Low }\end{array}$ & Total \\
\hline 1. & Urhobo & 1 & 2 & 3 & 6 & 12 \\
\hline 2. & Isoko & 2 & 4 & 3 & 5 & 14 \\
\hline 3. & Itsekiri & 0 & 2 & 4 & 12 & 18 \\
\hline 4. & Ijaw & 1 & 2 & 5 & 10 & 18 \\
\hline 5. & Ukwuani & 14 & 11 & 6 & 5 & 36 \\
\hline 6. & Ibo & 17 & 13 & 6 & 2 & 38 \\
\hline \multicolumn{2}{|c|}{ Total } & 35 & 34 & 27 & 40 & 136 \\
\hline
\end{tabular}

One of the factors that is responsible for the ethnic variation in the consumption of mushrooms is availability of the fungi, which is closely related to the vegetation of the area. The ethnic groups and settlements considered in this study traverse the various ecological zones thus; Ubogo (Freshwater Swamp forest), Otor-Owhe (Freshwater Swamp forest), Ugborodo (Mangrove forest), Bomadi (Mangrove forest), Beneku (Freshwater Swamp forest) and Agbor (Lowland rainforest) (See Figure 4). The pattern of mushroom consumption area increases from the coastal area with mangrove forest to the north with lowland rainforest; a woodier vegetation that provide more substrate for fungi growth. Thus, the availability of the fungi is dependent upon the ecology of the area. 


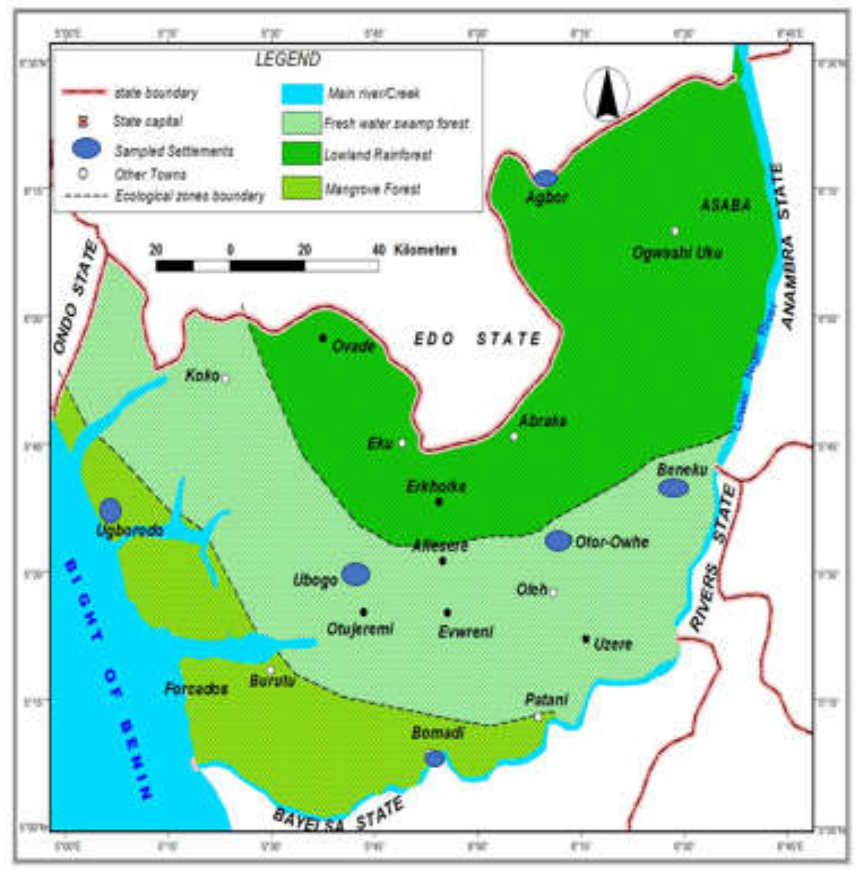

Fig 4: Ecological Zones of Study Area

Conclusion: The varied ecology of the study area provide substrate for the growth of a variety of edible mushrooms that are consumed for their nutritional and medicinal values by the various ethnic groups. The nature of the vegetation also influences the availability of the edible mushrooms and consequently the consumption pattern by the ethnic groups that traverse the study area. Following from the above, the study recommends the encouragement of the cultivation of edible mushrooms in order to make the fungi more available for desiring consumers.

\section{REFERENCES}

Adedokun, OM; Okomadu, CA (2017). Wild and domesticated Mushroom Consumption in Nigeria. African Crop Science Journal, Vol. 25 (1):123-131

Chang, ST; Miles, PG (1992). Mushroom Biology- A new discipline. Mycologist, 6: 64-65. doi: 10:1016/S0269-5X(09)8044-7

Chang, ST; Miles, PG (2004). Mushrooms: Cultivation, Nutritional Value, Medicinal Effect and Environmental Impact. Boca Raton, Florida, CRC Press (Revised Edition)

Donovan, P (2014). 'Postabelles'. www.mencola.com/mushrooms. Html. www. Buffalo. Edu/026.html
Hall, IR; Stephenson, SL; Buchanan, PK; Yun, W; Cole, ALJ (2003). Edible and poisonous Mushrooms of the World. Portland. Cambridge, Timber Press

Igben, JL (2014). Inland Sand Dredging and Economic Activities in the Niger Delta, Nigeria. Sacha Journal of Environmental Studies, 4(1):17.

Ikporukpo, CO (1996). Federalism, political power and economic power game; conflict over access to petroleum resources in Nigeria. Environment and Planning C, Government and Policy, 14(2): 159-177.

Jonathan, SG (2002). Vegetable growth requirements and antimicrobial activities of some higher Fungi in Nigeria. PhD thesis, University of Ibadan.

Jonathan, SG; Fasidi, IO (2003). Physiological Studies on Schizophyllum Commune (Fr. Ex. FR.), a Nigerian edible Mushroom. Bio. Res .Com. 15 (1): $15-22$

Kalu, IG; Nwachukwu, CU; Ijeoma, BC; EvansOkemba, CI (2013). Problems facing Mushroom availability and consumption in Owerri Municipal Council of Imo State, Nigeria. Journal of Biology, Agriculture and Healthcare, Vol. 3 (8):113-118

National Population Commission (NPC) (2006). Provisional population census report. Vanguard, Wednesday 10 January 2007. 
Okhuoya, JA; Akpaja, EO; Osemwengie, OO; Oghenekaro, AO; Ihayere, CA (2010). Nigerian Mushrooms: Underutilised Non-Wood Forest Resources. Journal of Applied Sciences and Environmental Management, 14(1):43-54.

Oyetayo, VO (2011). Medicinal uses of Mushrooms in Nigeria: Towards full and sustainable exploitation. African Journal of Traditional, Complementary and Alternative Medicines, 8(3): 267-274.
Yang, BK; Jeong, SC; Park, JB; Cho, SP; Lee, SD; Yun, JW; Lim, WJ; Song, CA (2001). Swimming Endurance Capacity of Mice after administration of Exo-polymer produced from submerged mycelial culture of Ganoderma lucidum. J. Microbe. Biotechnology. 11: 902 905 